\title{
Comparison of some reproductive characteristics of farmed and wild white shrimp males Litopenaeus vannamei (Decapoda: Penaeidae)
}

\author{
Sergio Rendón Rodríguez ${ }^{1}$, Emilio Macías Regalado ${ }^{1}$, José Antonio Calderón Pérez ${ }^{1}$, \\ Arturo Núñez Pastén ${ }^{1} \&$ Rafael Solís Ibarra ${ }^{2}$ \\ 1 Instituto de Ciencias del Mar y Limnología, Unidad Académica "Mazatlán”, Universidad Nacional Autónoma de \\ México, Aptdo. 811, Mazatlán 82000, Sinaloa, México Tel. (669) 98528 45; rendon@ola.icmyl.unam.mx. \\ 2 Facultad de Ciencias del Mar, Universidad Autónoma de Sinaloa. Paseo Claussen s/n, Mazatlán 82000, Sinaloa, \\ México. Tel. (669) 9828656.
}

Received 12-VII-2005. Corrected 28-III-2006. Accepted 15-XI-2006.

\begin{abstract}
We rated some reproductive characteristics of white shrimp Litopenaeus vannamei (Boone, 1931) males using 46 farmed individuals (weighing $21.42 \pm 0.56 \mathrm{~g}$ ) and 40 wild individuals (weighing $36.10 \pm 0.72 \mathrm{~g}$ ). In farmed shrimps, spermatophore mean weight was $8.94 \pm 0.51 \mathrm{mg}$; total mean sperm count was $3.90 \pm 0.27 \times 10^{6}$ in each spermatophore; and mean percentage of normal sperm was $86.9 \pm 0.37 \%$. In wild individuals, the respective values were $30.68 \pm 2.32 \mathrm{mg} ; 6.22 \pm 1.09 \times 10^{6}$; and $62.1 \pm 3.56 \%$. In both groups, the differences between right and left spermatophore were not significant $(p<0.01)$. There were significant differences in spermatophore weight and percentage of normal sperm between farmed and wild shrimps; sperm counts differences, however, were not significant $(\mathrm{p}<0.01)$. The relationship between spermatophore weight $(\mathrm{Ws})$ and individual weight (Wo) was Ws $(\mathrm{mg})=1.23$ (Wo)-17.34 $\left(\mathrm{r}^{2}=0.89\right)$, in farmed shrimps; and Ws $(\mathrm{mg})=2.57(\mathrm{Wo})-60.04\left(\mathrm{r}^{2}=0.64\right)$, in wild ones. In cultivated organisms, the relationship between sperm counts (Cs) and individual weight (Wo) was Cs (x $\left.10^{6}\right)=1.13^{*} 10^{-4 *}$ (Wo) $3.361\left(\mathrm{r}^{2}=0.85\right)$; and versus spermatophores weight was Cs $\left(\mathrm{x} 10^{6}\right)=0.439 *$ (Ws) 0.984 $\left(\mathrm{r}^{2}=0.90\right)$. In wild organisms, there was no correlation. The proportion of normal sperm ranged from 79.8 to 95.2 $\%(86.9 \pm 0.37 \%)$ and from 14.0 to $91.5 \%(62.1 \pm 2.52 \%)$, in farmed and wild shrimps, respectively. The most frequent abnormalities in both farm and wild animals were sperm without spike $(49.3 \%$ and $76.6 \%$, respectively) and irregular shape (35.8\% and $17.7 \%)$. The less frequent occurrences were those of bent $(10.2 \%$ and $4.29 \%$ ) and double spike (4.7\% and $1.41 \%$ ). Rev. Biol. Trop. 55 (1): 199-206. Epub 2007 March. 31.
\end{abstract}

Key words: Litopenaeus vannamei, reproduction, males.

The stocking of postlarvae for penaeid shrimp farming has passed through different stages from their collection in the wild to the capture of impregnated females for further spawning and rearing of larvae, up to the artificial manipulation of maturation of females, mating, spawning and rearing of larvae in laboratory facilities. In fact, the difficulty of closing the life cycle in the laboratory has been one of major obstacles for the establishment of shrimp culture as an industry (Chamberlain and Gervais 1984).

In the shrimp farming industry the control of reproduction in captivity is a critical factor for the success because this would guarantee the supply of postlarvae of a known species to be stocked and grown (Bray and Lawrence 1992). The development of techniques to induce maturation and reproduction in penaeid shrimps has been focused mainly on females, in spite of the fact that reproductive problems of males have been, in some instances, responsible for some of the reproduction failures in captivity of many penaeid species (Leung-Trujillo and Lawrence 1987). In Mexico, until a few years back, the main source for the initiation and renewal of breeding stock in maturation facilities was the feral population; however, because 
of the risks this group represents (potential carrying of virus and other diseases), as of late, the search for more reliable sources of breeding stock has become a necessity and the best alternative have been organism coming from culture facilities.

The objective of this work is to assess comparatively the reproductive potential of farmed and wild males of Litopenaeus vannamei to determine whether the former could also be used as breeding stock.

\section{MATERIALS AND METHODS}

A total of 86 organisms were utilized, 46 of which were collected from grow-out ponds of a farm in southern Sinaloa, Mexico. Their weight ranged from 15.44 to 28.47 g (mean $=21.42 \pm 0.56$ ). The remaining 40 individuals ranging from 28.15 to $45.56 \mathrm{~g}$ (mean $=36.10 \pm 0.72 \mathrm{~g}$ ), wet weight, were collected at sea on the southern Sinaloa continental shelf on board the $50 \mathrm{~m}$ long research vessel (B/O) "EL PUMA" by means of a commercial otter trawl-type net of 75 feet, off the mouths of the Presidio and Baluarte rivers, trawled at an average depth of $20 \mathrm{~m}$. The organisms were placed in circular plastic tanks of $0.50 \mathrm{~m}$ in diameter, in a room with controlled temperature $\left(\right.$ ca. $28^{\circ} \mathrm{C}$ ), at a salinity nearing that of the sea (around $34 \mathrm{ppt}$ ) and a photoperiod regime of 12:12 h. (light: darkness). A fresh-frozen diet consisting of a mixture of squid (Loliguncula sp. and Loliolopsis sp.) and small shrimps (Xiphopenaeus sp. and Rimapenaeus spp.); at a $1: 1$ ratio was supplied in a $15 \%$ proportion of the wet weight per day, distributed in two rations supplied at 09:00 and 17:00 h. In both, the remains of food and wastes were removed. Water exchange rate was maintained at $150 \%$ per day.

The parameters measured were: a) spermatophore weight; b) sperm count; and c) percentage of normal sperm. Spermatophores were ejected manually, applying a light pressure at the basis of the fifth pair of pereiopods on the side of the targeted organ to be ejected.
Spermatophore wet weight was measured, after excess water was removed, on an analytical balance to the nearest $0.005 \mathrm{mg}$. Subsequently, spermatophores were homogenized in a glass tissue grinder in $3.0 \mathrm{ml}$ of filtered and UV-sterilized seawater or in artificial seawater, prepared after Leung-Trujillo and Lawrence (1987).

Sperm counts were estimated from the average count of three samples of $0.0001 \mathrm{ml}$ each contained within an American Optical haemocytometer, using a microscope with a $40 x$ objective. The percentage of normal sperm was determined by direct observation of the samples in the haemocytometer counting the number of normal sperm (spherical body and straight and elongate spike) and the number of abnormal sperm (irregular form and bent, double, or missing spike) (Talbot et al. 1989).

Data of farmed and feral specimens weight, right and left spermatophores weight, sperm count and the percentage of normal sperm were statistically compared using a $t$-test for independent samples (Zar 1980); and with a modified $t$-test for unequal variances (Ott 1984). Sperm counts and percentage of normal sperm data were modified to make the variance independent of the mean, by taking the square root of $\mathrm{X}+3 / 8$ (Bray et al. 1985) and arcsine transformation (Leung-Trujillo and Lawrence 1985), respectively. The mean values are presented as Mean \pm standard error of the mean (SEM).

\section{RESULTS}

Tables 1 and 2 summarize pooled data of size, right and left spermatophores weight, sperm count and percentage of normal sperm of farmed and wild shrimps. Spermatophore weight of farmed shrimps ranged from 1.7 to $19.5 \mathrm{mg}(8.94 \pm 0.51 \mathrm{mg})$; and that of wild shrimps from 9.7 to $80.3 \mathrm{mg}(30.68 \pm 2.32$ $\mathrm{mg})$. In both, the differences among right and left spermatophores were not significant $\left(\mathrm{t}=0.015<\mathrm{t}_{0.01(2)} 90=2.632\right.$; and $\mathrm{t}=0.046<\mathrm{t}_{0.01(2)}$ ${ }_{78}=2.640$ ). The spermatophore weight $/$ shrimp weight ratio ranged from 0.010 to $0.068 \%$ 
TABLE 1

Comparison of right and left spermatophores weight (Ws), spermatophore weight/organisms weight ratio (Ws/Wo), sperm count and percentage of normal sperm of the farmed and wild Litopenaeus vannamei

Farmed

\begin{tabular}{lc}
\multicolumn{1}{c}{ Parameter } & Right \\
Ws $(\mathrm{mg})$ & $8.94 \pm 0.73$ \\
Ws $/$ Wo ratio $(\%)$ & $0.043 \pm 0.002$ \\
Sperm count $\left(\mathrm{x} 10^{6}\right)$ & $3.91 \pm 0.38$ \\
Normal sperm $(\%)$ & $86.96 \pm 0.48$
\end{tabular}

46
Wild

Spermatophores

$\begin{array}{cc}\text { Left } & \text { Right } \\ 8.93 \pm 0.73 & 30.61 \pm 2.42 \\ 0.043 \pm 0.002 & 0.082 \pm 0.005 \\ 3.90 \pm 0.38 & 6.25 \pm 1.10 \\ 86.74 \pm 0.48 & 62.49 \pm 3.51\end{array}$

46
Left

$30.76 \pm 2.21$

$0.083 \pm 0.005$

$6.19 \pm 1.08$

$61.76 \pm 3.67$

40

TABLE 2

Comparison of organisms weight (Wo), spermatophore weight (Ws), spermatophore weight/organisms weight ratio (Ws/Wo), sperm count and percentage of normal sperm between farmed and wild Litopenaeus vannamei

Parameter

Farmed

$21.42^{\mathrm{a}} \pm 0.56$

46

n

Ws (mg)

Ws/Wo ratio (\%)

$8.94^{\mathrm{a}} \pm 0.51$

$0.039^{\mathrm{a}} \pm 0.001$

$0.082^{b} \pm 0.002$

Sperm count (x 106)

$3.90^{\mathrm{a}} \pm 0.27$

$86.85^{\mathrm{a}} \pm 0.37$

92

$6.22^{\mathrm{a}} \pm 1.09$

Normal sperm (\%)

$\mathrm{N}$

Means with equal super index are not statistically different $(\mathrm{p}<0.01)$.

$(0.039 \pm 0.001 \%)$, in farmed shrimps; and from 0.034 to $0.183 \%(0.082 \pm 0.002 \%)$, in wild shrimps. In the latter, the difference was statistically significant $\left(\mathrm{t}=11.735>\mathrm{t}_{0.01(2) 147}=2.610\right)$, as well as for spermatophore weight among farmed and wild shrimps $\left(\mathrm{t}=12.714>\mathrm{t}_{0.01}\right.$ (2) ${ }_{95}=2.629$ ). In farmed shrimps, sperm count in each spermatophore ranged from $0.85 \mathrm{x}$ $10^{6}$ to $11.54 \times 10^{6}\left(3.90 \pm 0.27 \times 10^{6}\right)$; while that in wild shrimps ranged from $0.05 \times 10^{6}$ to $29.31 \times 10^{6}\left(6.22 \pm 1.09 \times 10^{6}\right)$, however, in spite of the apparent differences between the two groups, there were no significant differences in sperm counts between right and left spermatophores $\left(\mathrm{t}=0.021<\mathrm{t}_{0.01}\right.$ (2) $90=2.632$; and $\mathrm{t}=0.036<\mathrm{t}_{0.01}$ (2) $78=2.640$ ), nor in the sperm counts among farmed and wild shrimps $\left(\mathrm{t}=1.809<\mathrm{t}_{0.01(2) 111}=2.621\right)$.

Spermatophore weight (Ws) increases in relation to the organism weight (Wo) increase (Fig. 1A and 1B). The relationships of both, farm and wild shrimps are defined by the following regression equations:

$$
\begin{aligned}
& \text { Ws }(\mathrm{mg})=1.23(\mathrm{Wo})-17.34 ;\left(\mathrm{r}^{2}=0.89, \mathrm{p}<0.05\right) \\
& \text { Ws }(\mathrm{mg})=2.57(\mathrm{Wo})-60.04 ;\left(\mathrm{r}^{2}=0.64, \mathrm{p}<0.05\right)
\end{aligned}
$$

for farmed and wild shrimps, respectively; both were significant.

Similarly, sperm counts (Cs) in farmed shrimps increase in relation to increases of organism weight (Wo) (Fig. 2A) and spermatophore weight (Ws) (Fig. 3A). In both cases, a positive significant correlation was observed and the relationships are defined by the following regression equations:

$$
\operatorname{Cs}\left(x 10^{6}\right)=1.13 * 10^{-4 *}(\text { Wo }) 3.361 ;\left(\mathrm{r}^{2}=0.85, \mathrm{p}<0.05\right) \text {; }
$$

and

$$
\operatorname{Cs}\left(\mathrm{x} 10^{6}\right)=0.439 *(\mathrm{Ws}) 0.984 ;\left(\mathrm{r}^{2}=0.90, \mathrm{p}<0.05\right) .
$$



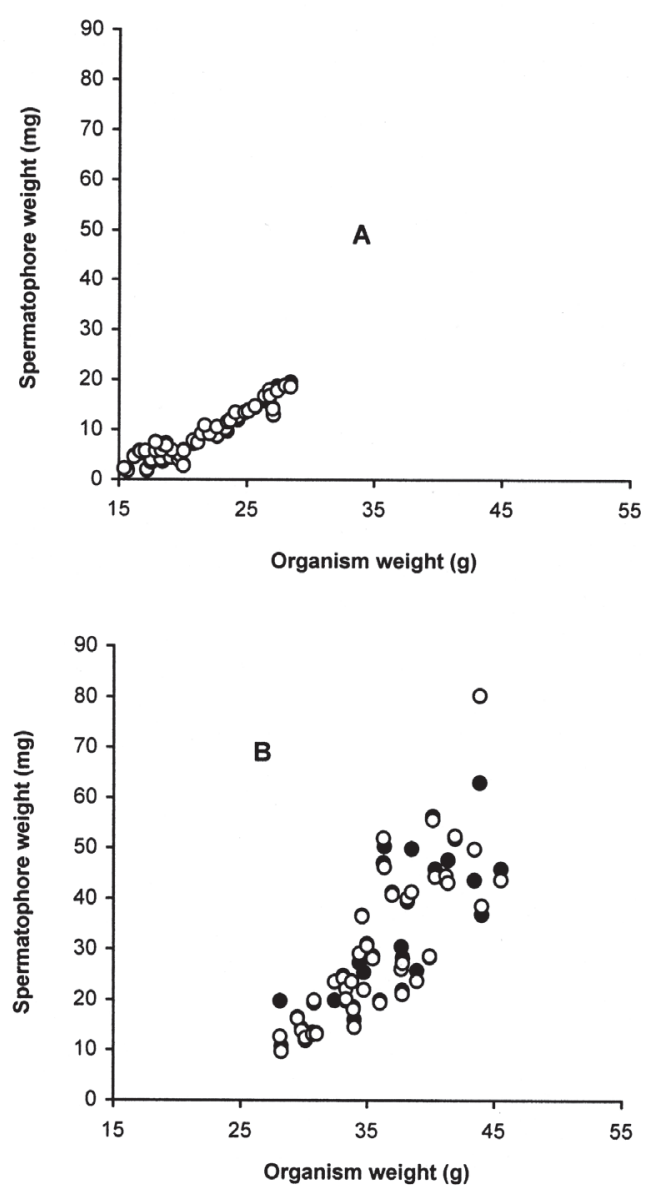

- Left ORight

Fig 1. Relationship between spermatophore weight and individual weight in farmed (A) and wild (B) Litopenaeus vannamei.

In wild shrimps, on the other hand, sperm count in relation to organism and spermatophore weights, was exceedingly variable. For example, in shrimps weighting 38 and $40 \mathrm{~g}$ with spermatophores of 28.5 and $39.5 \mathrm{mg}$, the sperm counts were $23.46 \times 10^{6}$ and $0.96 \times 10^{6}$, respectively. Therefore there was no correlation between these parameters in those males (Fig. $2 \mathrm{~B}$ and $3 \mathrm{~B})$.

In farmed shrimps, the proportion of normal sperm ranged from 79.8 to $95.2 \%$ $(86.85 \pm 0.37 \%)$; while that in wild shrimps
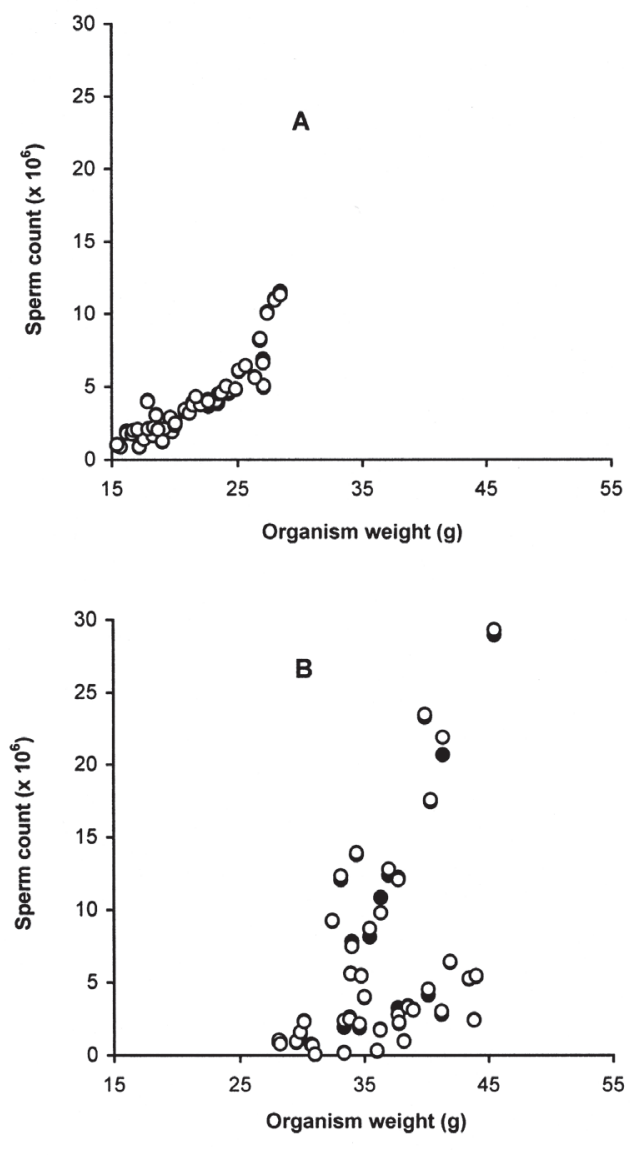

- Left ORight

Fig. 2. Relationship between sperm counts and individual weight in farmed (A) and wild (B) Litopenaeus vannamei.

ranged from 14.0 to $91.5 \%(62.12 \pm 2.52 \%)$. In both, the differences in the percentage of normal sperm between right and left spermatophores were not significant $\left(\mathrm{t}=0.234<\mathrm{t}_{0.01}\right.$ (2) ${ }_{90}=2.632$; and $\mathrm{t}=0.150<\mathrm{t}_{0.01}$ (2) $78=2.640$ ), but the differences in percentage of normal sperm between farmed and wild shrimps were significant $\left(\mathrm{t}=10.147>\mathrm{t}_{0.01}(2) 86=2.634\right)$.

Among farmed shrimps, 69 of the 92 spermatophores presented 80 to $90 \%$ of normal sperm; 14 more than $90 \%$ and 9 had between 70 and $80 \%$. In feral shrimps, only 24 of the 80 spermatophores presented a percentage of normal sperm between 80 and $90 \%$; 17 between 

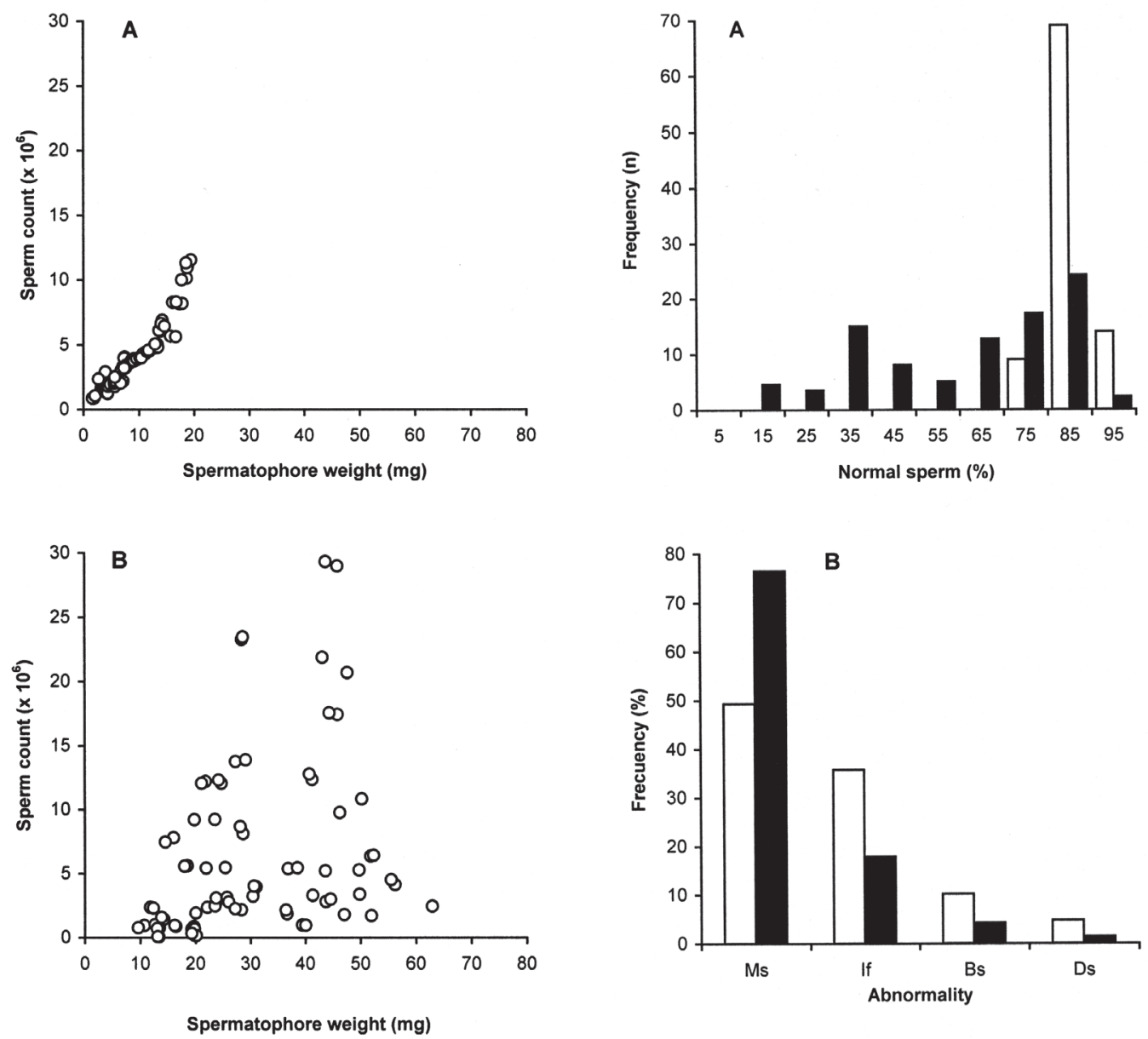

Fig. 3. Relationship between sperm counts and spermatophores weight of farmed (A) and wild (B) Litopenaeus vannamei.

70 and $80 \%$; 5 between 10 and $20 \%$; and in only two of the cases the proportion was higher than $90 \%$ (Fig. 4A).

Of the four types of abnormal sperm, in both farmed and wild shrimps, the most frequent were: missing spike (Ms; 49.3 and 76.6 $\%$, respectively) and irregular form (If; 35.8 and $17.7 \%$, likewise). Less frequent were those with bent (Bs; 10.2 and $4.3 \%$ ) and double spike (Ds; 4.7 and $1.4 \%$ ) (Fig. 4B).

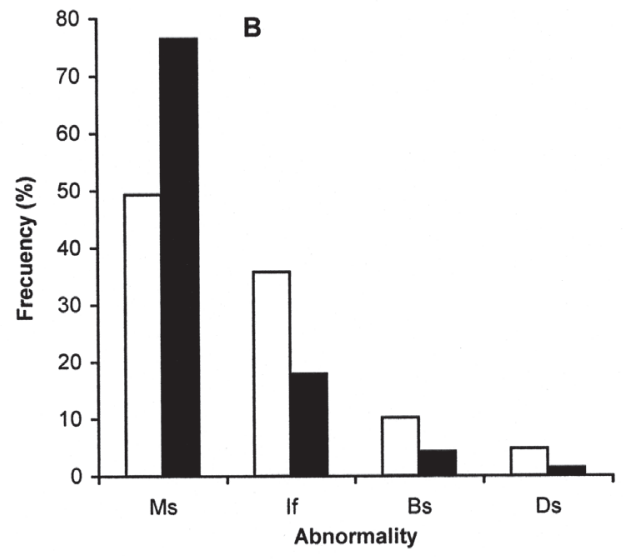

\section{口Farmed $\mathbf{W i l d}$}

Fig. 4. Frequency of normal sperm (A) and of abnormal sperm types (B) observed in farmed and wild Litopenaeus vannamei (Ms: missing spike; If: irregular form; Bs: bent spike; Ds: double spike).

\section{DISCUSSION}

In ponds, the presence of adult shrimp (joined petasma) of less than $20 \mathrm{~g}$ in weight is common. Although the maturation of males in penaeid shrimps does not require special environmental or nutritional conditions, is not very clear as yet, if such maturation is related to size or age. L. vannamei males, 6.5 months old, of $12.51 \mathrm{~g}$, present well developed spermatophores 
(Ogle 1992). On the other hand, in the marine environment, shrimps of the same species, weighting more than $20 \mathrm{~g}$, are still sexually immature. The minimum weight of sexually mature shrimp males of this species is $21.13 \mathrm{~g}$ (Calderon-Perez et al., unpubl.).

In farmed shrimps of size between 15 and $30 \mathrm{~g}$, the values of spermatophore weight (1.7 to $19.5 \mathrm{mg})$, sperm counts $\left(0.85 \times 10^{6}\right.$ to $\left.11.54 \times 10^{6}\right)$ and percentage of normal sperm (79.8 to $95.2 \%$ ), were proportionally higher than those found elsewhere. Leung-Trujillo and Lawrence (1985) reported similar values although in males bigger than $30 \mathrm{~g}$ while Alfaro and Lozano (1993) reported much lower sperm counts and percentage of normal sperm in shrimps of size between 22 to $25 \mathrm{~g}$.

The considerably high values of the correlation coefficients between organism and spermatophore weight $\left(\mathrm{r}^{2}=0.89\right)$, and between spermatophore weight and sperm count $\left(\mathrm{r}^{2}=0.85\right)$, and of the percentage of normal sperm $(79.8$ to $95.2 \%)$ appears to indicate that these organisms were in a stage of first maturity and therefore the spermatophores would have been recently deposited in the terminal ampoules of the males. In this regard, Alfaro and Lozano (1993) observed a deterioration of the spermatophores of $P$. vannamei within a period of two to three months, in farm ponds. It also suggests that such deterioration is a normal occurrence in the reproduction process of penaeid shrimps. Feral shrimps on the other hand, although bigger (28 to $46 \mathrm{~g}$ ), and with higher spermatophore weight range (9.7 to 80.3 $\mathrm{mg}$ ), did not show proportional higher values in the reproduction parameters examined as it would be expected, i.e., sperm count $(0.05 \mathrm{x}$ $10^{6}$ to $29.31 \times 10^{6}$ ) and percentage of normal sperm were extremely variable (14 to $91.5 \%$ ).

The former is probably due to the aforementioned deterioration of the spermatophores, which is manifested as the high variability of sperm count and percentage of normal sperm. The low but acceptable correlation coefficient observed between organism weight and spermatophore weight $\left(r^{2}=0.64\right)$ and the lack of correlation between the organism weight and the spermatophore weight with sperm counts and the low percentage of normal sperm seem to strengthen this argument with regards to the amount and quality of the sperm. What the above actually means is that the presence of spermatophore of good size and appearance does not always guarantee good sperm counts and adequate percentage of normal sperm.

According to Leung-Trujillo and Lawrence (1987) the deterioration of spermatophores in captive $P$. setiferus is a predictable event, and to Talbot et al. (1989), the bacterial infection is not the primary cause of this problem. Alfaro (1990), Gomes and Primavera (1993) pointed out that the reproductive performance of many species of crustacean is affected by the water quality and the stress conditions.

The results of the evaluation of the spermatophore of wild shrimps indicates that their deterioration is a natural process. In this regard, Alfaro and Lozano (1993) suggest that such deterioration is a natural way of getting rid of old spermatophores. Leung-Trujillo and Lawrence (1985) found that young specimens of $P$. vannamei have early and small spermatophores. In this study, the spermatophore weight of farmed shrimps represented, in average, $0.039 \%$ of the organism weight, about half of that observed in wild shrimps $(0.085 \%)$.

In relation to sperm quality, Motoh (1981), Leung- Trujillo and Lawrence (1985) and Alfaro (1993) coincide that in penaeid shrimps the highest percentages of abnormal sperm occur in young organisms; however, in this work, the higher percentages of abnormal sperm $(86.0 \%)$ were observed in wild, bigger and presumable older shrimps while in farmed shrimps of approximately five to six months of age, that percentage was relatively low $(20.2$ $\%)$. This is also attributed to the above mentioned process of deterioration.

Among the sperm abnormalities, the highest percentages were those of the body without spike, in both farmed (49.3\%) and wild shrimps $(76.6 \%)$. The latter is similar to the 77 $\%$ observed by Leung-Trujillo and Lawrence (1985). It would appear that this type of abnormality is also the most frequent in P. monodon 
since Pratoomchat et al. (1993) found more than $95 \%$ of sperm without spike out of the totality of abnormal sperm.

The importance of the appearance lies in the fact that abnormal or deformed spermatozoa do not have the same capability for ovule fertilization as normal or non-deformed spermatozoa have (Motoh 1981). The spermatozoa spike in rock shrimp Sicyonia ingentis seems to be required for the orientation of the sperm and subsequent penetration in the ovule (Clark et al. 1981).

In conclusion, the weight of the organisms and the weight of the spermatophore were significantly higher in feral than in farmed male shrimps; however, even though spermatozoid counts were also higher in wild than in farmed specimens $(6.22 \pm 1.09$ and $3.90 \pm 0.27$ million) the difference was not significant.

The percentage of normal spermatozoids was significantly higher in farmed than in feral males.

The last item lead us to suggest that in spite of the higher proportion in spermatophore weight and spermatozoid count of feral males, the higher percentage of normal spermatozoids in farmed shrimps compensates such inequalities, making farmed males a more reliable source of spermatozoids for female fertilization given their availability and consistency. This would be particularly important in laboratories where artificial insemination is practiced.

\section{ACKNOWLEDGMENTS}

Thanks are due to the technical staff of the Parque Camaronicola of the Federación de Cooperativas "Guerreros del Sur", to the Fisheries Biologists Jesus Peiro L. and Enrique Lopez B., for the donation of the organisms; to the crew and Captain of the B/O "El Puma", for their support in the collection of shrimp at sea; and to Hugo A. López C., Jorge G. Gaona M. and Edna E. Aguilar Abrego, for their collaboration.

\section{RESUMEN}

Se evaluaron características reproductivas como peso del espermatóforo, número de espermatozoides y porcentaje de espermatozoides normales en 86 organismos de camarón blanco (Litopenaeus vannamei). De éstos, 46 individuos provinieron de estanques de cultivo con un peso de $21.42 \pm 0.56$ g y el resto, 40 , silvestres con un peso de $36.10 \pm 0.72$ g. En los camarones cultivados, el peso de los espermatóforos fue de $8.94 \pm 0.51 \mathrm{mg}$; el número total de espermatozoides en cada espermatóforo fue de $3.90 \pm 0.27$ x $10^{6}$; y el porcentaje de espermatozoides normales fue de $86.9 \pm 0.37 \%$. En los silvestres, los valores respectivos fueron de $30.68 \pm 2.32 \mathrm{mg} ; 6.22 \pm 1.09 \times 10^{6}$; y $62.1 \pm 3.56 \%$. En ambos grupos, las diferencias entre los espermatóforos derecho e izquierdo no fueron estadísticamente diferentes $(p<0.01)$. Las diferencias en el peso de los espermatóforos y el porcentaje de espermatozoides normales, entre los camarones cultivados y silvestres, fueron significativas $(\mathrm{p}<0.01)$; sin embargo, en el número de espermatozoides tales diferencias no fueron significativas $(\mathrm{p}<0.01)$. La relación entre el peso del espermatóforo (Ws) y el peso de los individuos (Wo) fue Ws $(\mathrm{mg})=1.23$ (Wo)-17.34 $\left(\mathrm{r}^{2}=0.89\right)$, en camarones cultivados; y Ws $(\mathrm{mg})=2.57(\mathrm{Wo})-60.04\left(\mathrm{r}^{2}=0.64\right)$, en los silvestres. En organismos cultivados, la relación entre el número de espermatozoides (Cs) y el peso de los individuos (Wo) fue $\operatorname{Cs}\left(* 10^{6}\right)=1.13 * 10^{-4 *}$ (Wo) $3.361\left(\mathrm{r}^{2}=0.85\right)$; y entre el peso de los espermatóforos fue $\operatorname{Cs}\left(* 10^{6}\right)=0.439 *$ (Ws) $0.984\left(\mathrm{r}^{2}=0.90\right)$. En el caso de los organismos silvestres, no hubo correlación. La proporción de esperma normal varió de 79.8 a $95.2 \%(86.9 \pm 0.37 \%)$ y de 14.0 a $91.5 \%(62.1 \pm 2.52$ $\%)$, en camarones cultivados y silvestres, respectivamente. Las anormalidades más frecuentes tanto en los cultivados como en los silvestres fueron esperma sin spike (49.3\% y $76.6 \%$, respectivamente) y los de forma irregular (35.8 \% y $17.7 \%$ ). Las presencias menos frecuentes fueron las de spike torcido ( $10.2 \%$ y $4.29 \%$ ) y doble $(4.7 \%$ y $1.41 \%)$.

Palabras clave: Litopenaeus vannamei, reproducción, machos.

\section{REFERENCES}

Alfaro, J. 1993. Reproductive quality evaluation of male Penaeus stylirostris from grow-out pond. J. World Aquacult. Soc. 24: 6-11.

Alfaro, J. \& X. Lozano. 1993. Development and deterioration of spermatophores in pond-reared Penaeus vannamei. J. World Aquacult. Soc. 24: 522-529.

Bray, W.A., J. Leung-Trujillo \& A.L. Lawrence. 1985. Preliminary investigation on the effects of temperature, 
bacterial inoculation, and EDTA on sperm quality in captive Penaeus setiferus. J. World Maricult. Soc. 16: 250-257.

Bray, W.A. \& A.L. Lawrence. 1991. Reproduction of Penaeus species in captivity, p. 93-170. In A.W Fast \& L.J. Lester (Eds.) Culture of marine shrimp: Principles and practices, Elsevier, Amsterdam, Holland.

Clark, W.H.Jr., M.G. Kleve \& A.I. Yudin. 1981. An acrosome reaction in natantia sperm. J. Exp. Zool. 218: 279-291.

Chamberlain, G.W. \& N.F. Gervais. 1984. Comparison of unilateral eyestalk ablation with enviromental control for ovarian maturation of Penaeus stylirostris. J. World Maricult. Soc. 15: 29-30.

Gomes, L.A.O. \& J.H. Primavera. 1993. Reproductive quality of male Penaeus monodon. Aquacult. 112: 157-164.

Leung-Trujillo, J.R. \& A.L. Lawrence. 1985. The effect of eyestalk ablation on spermatophore and sperm quality in Penaeus vannamei. J. World Maricult. Soc. 16: $258: 266$.

Leung-Trujillo, J.R. \& A.L. Lawrence. 1987. Observations on the decline in sperm quality of Penaeus setiferus under laboratory conditions. Aquacult. 65: 363-370.

Motoh, H. 1981. Studies on the fisheries biology of the giant tiger prawn, Penaeus monodon, in the Philippines. Tech. Paper No. 7, Aquacult. Dep.
Southeast Asian Fish. Development Center, Tigbauan, Iloilo, Philippines, 128 p.

Ogle, J.T. 1992. A review of the current (1992) state of our knowledge concerning reproduction in open thelycum Penaeid shrimp with emphasis on Penaeus vannamei. Invert. Reprod. Develop. 22: 267-274.

Ott, L. 1984. An introduction to statistical methods and data analysis. Duxbury. Boston, Massachusetts, USA.

Pratoomchat, B., S. Piyatiratitivorakul, P. Menasveta \& A.W. Fast. 1993. Sperm quality of pond-reared and wild-caught Penaeus monodon in Thailand. J. World Maricult. Soc. 24: 530-540.

Primavera, J.H. 1980. Studies on broodstock of sugpo Penaeus monodon Fabricius and other penaeids at the SEAFDEC Aquaculture Departament. Contribution no. 58 SEAFDEC Aquaculture Dept. Paper presented at International Symposium Coastal Aquaculture 12-18 January 1980, Cochin, India, $24 \mathrm{p}$.

Rosenberry, R. 2002. World shrimp farming 2001. Aquacult. Digest, San Diego, California, USA. 28 p.

Talbot, P., D. Howard, J. Leung-Trujillo, T.W. Lee, W.Y. Li, H. Ro \& A.L. Lawrence. 1989. Characterization of male reproductive tract degenerative syndrome in captive penaeid shrimp (Penaeus setiferus). Aquacult. 78: 365-377.

Zar, J.H. 1980. Biostatistical analysis. Prentice Hall, Englewood Cliffs, New Jersey, U.S.A. 